How to cite this article:

Mohd Radzi, S. H., Tan, W. H., \& Yusoff Shipping Management Simulation Game for Teaching and Learning in Higher Education: A Quasi-Experimental Study. Malaysian Journal of Learning and Instruction, 16(2), 155-186.

\title{
SHIPPING MANAGEMENT SIMULATION GAME FOR TEACHING AND LEARNING IN HIGHER EDUCATION: A QUASI- EXPERIMENTAL STUDY
}

\author{
${ }^{1}$ Shanizan Herman Mohd Radzi, Wee Hoe Tan \& Amri Yusoff \\ School of Quantitative Sciences, Universiti Utara Malaysia, \\ Malaysia \\ ${ }^{1,2 \& 3}$ Faculty of Art, Computing and Creative Industry \\ Universiti Pendidikan Sultan Idris, Malaysia \\ ${ }^{1}$ Coresponding author: shahnizan@uum.edu.my
}

Received: 28/2/2019 Revised: 8/10/2019 Accepted: 15/10/2019 Published:24/12/2019

\begin{abstract}
Purpose - This study examines the effects of a simulation board game for teaching and learning shipping management in higher education. A framework of comprehensive shipping operations is developed according to the syllabus of the Shipping Management course at Universiti Utara Malaysia. The course core content in the game covers two main services-liner services and tramp services in the shipping industry.

Methodology - A quasi-experimental research design was adopted to measure the effectiveness of the board game in giving students some understanding about shipping operations. Data were gathered from a sample of 73 undergraduate students enrolled in a Shipping Management course, using a non-equivalent control group design. The data were analysed using the McNemar Test to determine the level of understanding in shipping operations.
\end{abstract}

Findings - It was found that using the board game in learning activities contributed to the improvement of students' knowledge 
and skills. A performance comparison indicated that there were differences in students' achievement for the tramp services and liner services contents.

Significance - The framework for the shipping management board game aims to provide the best learning experience for students when they immerse themselves in solving problems and making decisions in the game. The framework can be used as a benchmark in the practice of game-based learning, particularly by affording students the opportunity to engage in learning by doing. Furthermore, this framework introduces a tangible problem space through the board game, encouraging students to discover knowledge at their own pace in a non-threatening environment.

Keywords: Simulation board game, shipping management, gamebased learning, game mechanics, intended learning outcomes.

\section{INTRODUCTION}

The shipping industry is a global industry in which most trade and commerce presently take place (UNCTAD, 2015). The industry enables a global supply chain to source products from all over the world (Allate, 2015). This is constantly regarded as a top priority in the global industry, hence making shipping management a crucial discipline, particularly the operations management of the shipping industry.

Fundamentally, shipping management focuses on the management aspects of the shipping operation. These aspects include technical management, quality and safety management, procurement, crewing and financial management services and functions (Jahn \& Bussow, 2013). Despite Malaysia's aim to be a leading shipping hub in Southeast Asia, few Malaysian academic institutions offer shipping management as a course in their logistics and transportation programme. One institution that does so is Universiti Utara Malaysia (UUM), which includes a Maritime Management course in its Bachelor of Business Administration (Logistics and Transportation) programme ("Programme Structure (L\&T) - UUM," 2016).

According to Yusof, Radzi, Khalid and Din (2016), the main issue regarding learning about shipping management is students' inability 
to visualize the application of theories in logistics that they learn through mass lectures. This hampers their understanding during and beyond the process of learning. Being incapable of visualizing how theories could be applied might hinder students from comprehending lecture contents (Jaipragas, 2017). Hence, students need an alternative media to support the learning process, specifically to make theories introduced in the course easier to understand and apply, allowing them to continuously discover knowledge at their own pace.

The design of this particular board game involved sixteen modules which were simplified from a comprehensive shipping operation. All modules were then converted into a playing phase for each game round. There are three main phases for each game round which involve planning, operation and procurement/clean-up phase. The mechanics of the game are 'pickup and deliver' where players will pick up any open contracts in the planning phase and deliver the contract in the procurement/clean-up phase. Area movement mechanic is used in the operation phase so as to portray the movement of the owned ships across the continent to reach its destination.

According to the literature, the use of games in education supports the provision of meaningful experience, especially during the learning process, with engaging practice (Ahmad, Radzi, \& Radzi, 2017; McCarthy, 2014; Minnery \& Searle, 2012; Yusof et al., 2016). In the context of education, a game is "an activity which is participated by individuals for the purpose of entertainment, especially in competitive activities that are arranged by the rules, and of which the results will be determined by the skill, strength, or luck of the individual" (Tan, 2015). When games are used in formal education contexts, game-based learning practice is able to drive students to explore knowledge at their own pace, affording students to construct their knowledge and understanding (Tan, Johnston-Wilder, \& Neill, 2011). The play session that occurs between learners and the game environment is able to help them in visualizing scenarios and problems they encounter, prompting the need to comprehend and solve. Therefore, the use of games in educational settings is useful, especially when students try to visualize something that they are unfamiliar with (Lennon \& Coombs, 2007; Radzi, Abidin, Zainol, $\&$ Ahmad, 2015a). Such practices are able to provide good exposure 
in areas that require the students to comprehend, analyze, and synthesize in order to attain the intended learning outcomes.

This study explored the potential of board games in order to propose a framework of simulation board game playing experience for learning shipping operations. Making a play session meaningful would allow a sensible learning experience to occur (Cherif, Jedlicka, Verma, Uddin, \& Movahedzadeh, 2017). In order to empower and encourage students to visualize problems in the contexts of shipping management, a board game entitled "Shipping Management" was designed and developed as a learning tool for students to learn about shipping operations.

\section{LITERATURE REVIEW}

\section{Board Games versus Digital Games}

Board games can be considered as a simulation tool that is identical to computer simulations (Cushman-Roisin, Rice, \& Moldaver, 2000). Thus, the flow of playing a board game can represent general processes of any operation. Cushman-Roisin, Rice, and Moldaver (2000) further described that even though computer simulation in digital games was considered the best of its kind due to its high processing capability, especially in replicating real scenarios, board games could demonstrate strengths in other aspects. For instance, board games encourage face-to-face interaction between players, foster a meaningful and reflective environment for understanding a certain domain of knowledge, present transparent processes of an operation from a selected theme, and enable players to be involved directly in the game world to make decisions creatively (Dahlin, Larsson, \& Erlich, 2013; Radzi et al., 2015a). Nowadays, the aforementioned strengths are available in most modern board games. In addition, the experience gained by board game players when immersing in the game world happens in a non-threatening physical environment.

The general strengths of board games can be transferred into the creation of a specific board game for the learning of shipping management. Through the use of tangible user interface, the game 
can provide targeted players with the real application of domain knowledge and simulate scenarios of problems and challenges. A tangible user interface enforces the use and manipulation of physical or tangible objects as its main interface for the environment that it represents (Bagwan, Bias, Ahuja, \& Bagde, 2016; Schneider, Blikstein, \& Mackay, 2012). In spite of looking at the computer screen and clicking command buttons, board game players need to touch tokens, count chips and paper money, move pieces around game boards, and negotiate deals face-to-face with other players. Hence, players can learn by doing and by visualizing what a computer would do for them, which is otherwise in a normal digital simulation game. Communication among players would be less structured as compared to computer games, since their communication and interaction when dealing with certain problems and challenges in the game are not limited to predetermined options set by computer programmers. In other words, the nature of low tech board games actually provides an added advantage, in addition to their portability. Furthermore, board games are not bound by digital technology; therefore it has better sustainability than digital games (Dahlin et al., 2013; Eterovic \& Santos, 2013). Examples of such board games are Monopoly and Scrabble published by Hasbro.

\section{Board Games in Shipping Management}

Approaches in teaching and learning through games highlight how to actively facilitate knowledge construction among students, while reducing their need to receive knowledge passively from lectures (Li, 2010; Prensky, 2001). The use of games in learning activities provides the creation of a problem-solving space in real life environments (Mayer \& Wittrock, 2006), real-time collaboration and team activities such as inquiry-based learning (Jong \& Shang, 2015; Veloo, Md-Ali, \& Chairany, 2016). The implementation of the board game in the shipping management course could be regarded as a practice of game-based learning. The potential of game-based learning practices has been recognised as an effective means of engaging students within the achievement of a specific purpose, capturing their interest towards a subject matter, and developing new skills and knowledge (De Lope, Medina-Medina, Paderewski, \& Gutierrez-Vela, 2015; Huang \& Levinson, 2012; Spring, 2015; Zin, Jaafar, \& Yue, 2009). 
Ultimately, game-based learning in shipping management may provide learning experience from various angles, as it provides a platform for students to explore all kinds of possibilities and to discover all possible outcomes. The experimentation features in the game can be reflected through logistic activities on a small scale, making it evolve within the game environment. This would drive students to foster logistic innovation that may improve two types of shipping services (Allate, 2015). Furthermore, game-based learning may cultivate and promote individual social skills that may support traditional learning methods (Hung, Young, \& Lin, 2013; Nunohiro, Matsushita, Mackin, \& Ohshiro, 2013; Podolefsky, 2012). What is more, the need for social interaction through immersive learning experience is crucial to meet the demand for soft skills development, allowing students to adapt to the changes over time (de Freitas, 2008). Hence, in order to measure the effectiveness of the board game in fostering some understanding of the learning context during the in-game session, a pre-test and post-test quasi-experimental group design were used to examine the cause and effect of such treatment between two groups (Ober, 2017). These measures were used to conclude whether the Shipping Management Game would have an impact in fostering knowledge in shipping management.

In general, two types of board games have been developed for learning logistics. One focuses on activities in the fishing industry; while another focuses on the operations of a port (Radzi, Abidin, Zainol, \& Ahmad, 2015b, 2017). In particular, some game developers have developed commercial off-the-shelf (COTS) board games which simulate the shipping industry, although they are not specifically inclined towards education. The North Atlantic Shipping Game, Tycoon: The International Shipping Game, Shipping Empires and Shipping Forecast are examples of COTS shipping management games (Canning, 2013; Pearson, 1976; Saunders, 2004; "The north atlantic shipping game [Board game]," 1980). These board games have achieved commercial success, creating entertainment value for players.

\section{METHODOLOGY}

A quasi-experimental research design was adopted for this study. A non-equivalent control group design was used in order to measure the effectiveness of board game learning. 


\section{Participants of the Study}

This study researched post-learning activities using a medium of game-based learning in higher education. The participants were students enrolled in a course titled Shipping Management (BPMG3083), offered by the School of Technology Management and Logistics, Universiti Utara Malaysia. There were 73 students comprising 53 females and 20 males within the age range of $20-25$ years old.

The research design was reinforced with pre-test and post-test exercises aiming at determining the impact and influence of the different post-learning activities. Two groups were created from one class for the purpose of the study: a control group and an experimental group. One comparison group was assigned randomly using a computer random number generator as the control group (n $=38$ ) that was not exposed to any post-learning activities. The other group, i.e., the experimental group $(n=35)$, was exposed to the use of the board game as their post-learning activities. All participants in this research received a consent form to give permission to the researcher to include them in the experiment; those who did not sign the consent form were excluded.

\section{Instruments}

For the purpose of this study, 15 questions were used as the pretest and post-test for the participants. Five of the questions were from the topic of general logistics (sea transportation) (GLQ), three from tramp services (TSQ), four from liner services (LSQ) and the remaining three questions were from tramp and liner services (T\&LSQ). All questions were selected by the researcher from the shipping management course question bank of the School of Technology Management and Logistics, and validated by a panel of experienced logistics lecturers.

The first section of the test assessed participants' knowledge on the basic concept of sea transportation (GLQ). The second and the third sections tested the basic concept and applications of tramp services and liner services respectively (TQS and LSQ). The final section was aimed at assessing students' ability to differentiate between tramp services and liner services in a shipping management context 
(T\&LSQ) (see Table 1). All questions were multiple choice items. In order to control for the testing effect, the duration between the pretest and post-test, and the number of questions tested were sufficient to prevent students from memorizing the questions. Furthermore, the order of the questions for the pre-test and the post-test were changed.

\section{Table 1}

Test Items Included in the Data Collection Instrument for Pre-Test and Post-Test

\begin{tabular}{|c|c|c|}
\hline Classification / Topic & Question & $\begin{array}{c}\text { Alignment to feature in Shipping } \\
\text { Management Game }\end{array}$ \\
\hline \multirow[t]{5}{*}{$\begin{array}{l}\text { General logistic (Sea } \\
\text { transportation) }\end{array}$} & $\begin{array}{l}\text { What is the definition of port in terms } \\
\text { of maritime? }\end{array}$ & \multirow{5}{*}{$\begin{array}{l}\text { Selection of port, classification } \\
\text { of other port in the game } \\
\text { environment, identifying route } \\
\text { and connectivity of shipping } \\
\text { line and planning for the best } \\
\text { profitable port to head first in } \\
\text { making delivery }\end{array}$} \\
\hline & $\begin{array}{l}\text { What is not a factor for choosing } \\
\text { location and design of port? }\end{array}$ & \\
\hline & $\begin{array}{l}\text { Which of the following is not the role } \\
\text { of government in port development? }\end{array}$ & \\
\hline & $\begin{array}{l}\text { Which of the following is not a factor } \\
\text { in choosing a port in a country by user } \\
\text { and ship owner? }\end{array}$ & \\
\hline & $\begin{array}{l}\text { Which of the following features are } \\
\text { not true for port competition? }\end{array}$ & \\
\hline \multirow[t]{3}{*}{ Tramp shipping } & $\begin{array}{l}\text { Which of this statement provides the } \\
\text { best definition of tramp services? }\end{array}$ & \multirow{3}{*}{$\begin{array}{l}\text { Perform tramp shipping when } \\
\text { fulfilling shipping contracts, } \\
\text { planning for future delivery, } \\
\text { organize tramp shipping for } \\
\text { highest profit. }\end{array}$} \\
\hline & $\begin{array}{l}\text { Choose the criteria which fit tramp } \\
\text { ships. }\end{array}$ & \\
\hline & $\begin{array}{l}\text { Which of the following regarding the } \\
\text { bareboat chartering system is true? }\end{array}$ & \\
\hline \multirow[t]{4}{*}{ Liner shipping } & $\begin{array}{l}\text { Which statement here is true regarding } \\
\text { the liner shipping? }\end{array}$ & \multirow{4}{*}{$\begin{array}{l}\text { Planning route of selection for } \\
\text { liner shipping, perform liner } \\
\text { shipping when fulfilling shipping } \\
\text { contracts, integrate shipping line } \\
\text { among other ships. }\end{array}$} \\
\hline & $\begin{array}{l}\text { During harbouring at ports, liner ships } \\
\text { usually takes precedence over tramp } \\
\text { ships. Which of the following is true } \\
\text { regarding the reason of this harbouring } \\
\text { rule? }\end{array}$ & \\
\hline & $\begin{array}{l}\text { A ship that operates within a schedule } \\
\text { and has a fixed port rotation with } \\
\text { published dates of call at the advertised } \\
\text { port is a ... }\end{array}$ & \\
\hline & $\begin{array}{l}\text { Choose the criteria which fit liner } \\
\text { ships. }\end{array}$ & \\
\hline \multirow[t]{3}{*}{$\begin{array}{l}\text { Tramp shipping and } \\
\text { liner shipping }\end{array}$} & $\begin{array}{l}\text { Which of the following concerning } \\
\text { liner and tramp ships is true? }\end{array}$ & \multirow{3}{*}{$\begin{array}{l}\text { Identifying the best services of } \\
\text { shipping method with highest } \\
\text { profit, optimising ships load } \\
\text { when making delivery. }\end{array}$} \\
\hline & $\begin{array}{l}\text { In terms of vessel operation, liner and } \\
\text { tramp vessel have similarities in which } \\
\ldots\end{array}$ & \\
\hline & $\begin{array}{l}\text { What is the advantage of flag } \\
\text { discrimination? }\end{array}$ & \\
\hline
\end{tabular}




\section{Procedure}

The study was conducted within 10 weeks, and comprised 10 sessions of post-learning meetings for the treatment group (from $17^{\text {th }}$ September 2017 to $15^{\text {th }}$ December 2017). At the start of the field testing, all participants attending the 'Shipping Management' course answered the pre-test questions in their respective lecture halls. In the same week, the treatment group was given a review of gameplay; namely the Shipping Management Game. Within the first treatment session, participants were exposed to the components of the game and how it represented the realistic elements in the shipping environment.

The treatment group started playing the board game in the second week of the field testing and continued playing the game until the tenth week. Prior to the participants' interaction with the board game, they were given comprehensive oral instructions regarding the game's rules by two instructors. The instructors were selected among the lecturers in the same domain. The instructors helped the participants to set up the board game and explained the game turn as well as game end conditions. The instructors were forbidden from disclosing to participants any strategies that may lead to winning the game, but they were allowed to assist participants in understanding the rules and flow of the game. At the end of the field testing, the post-test was administered to both groups to measure the effect of playing the board game. Participants who presented themselves in either the pre-test or the post-test had to retake the test in the following week.

\section{DEVELOPMENT OF THE SIMULATION BOARD GAME}

\section{Framework of the Simulation Board Game}

The development of a simulation board game considers the alignment of the framework with the course content and domain expert while maintaining the flow state of players. In order to develop such a board game, the flow of a comprehensive shipping operation must be constructed. The process flow identified was based on the chosen main theme, which was either liner or tramp shipping. A simulation framework was created in order to design a board game which contained specific course contents. The framework simplified key processes of shipping management that occur in the gameplay, as shown in Figure 1. 


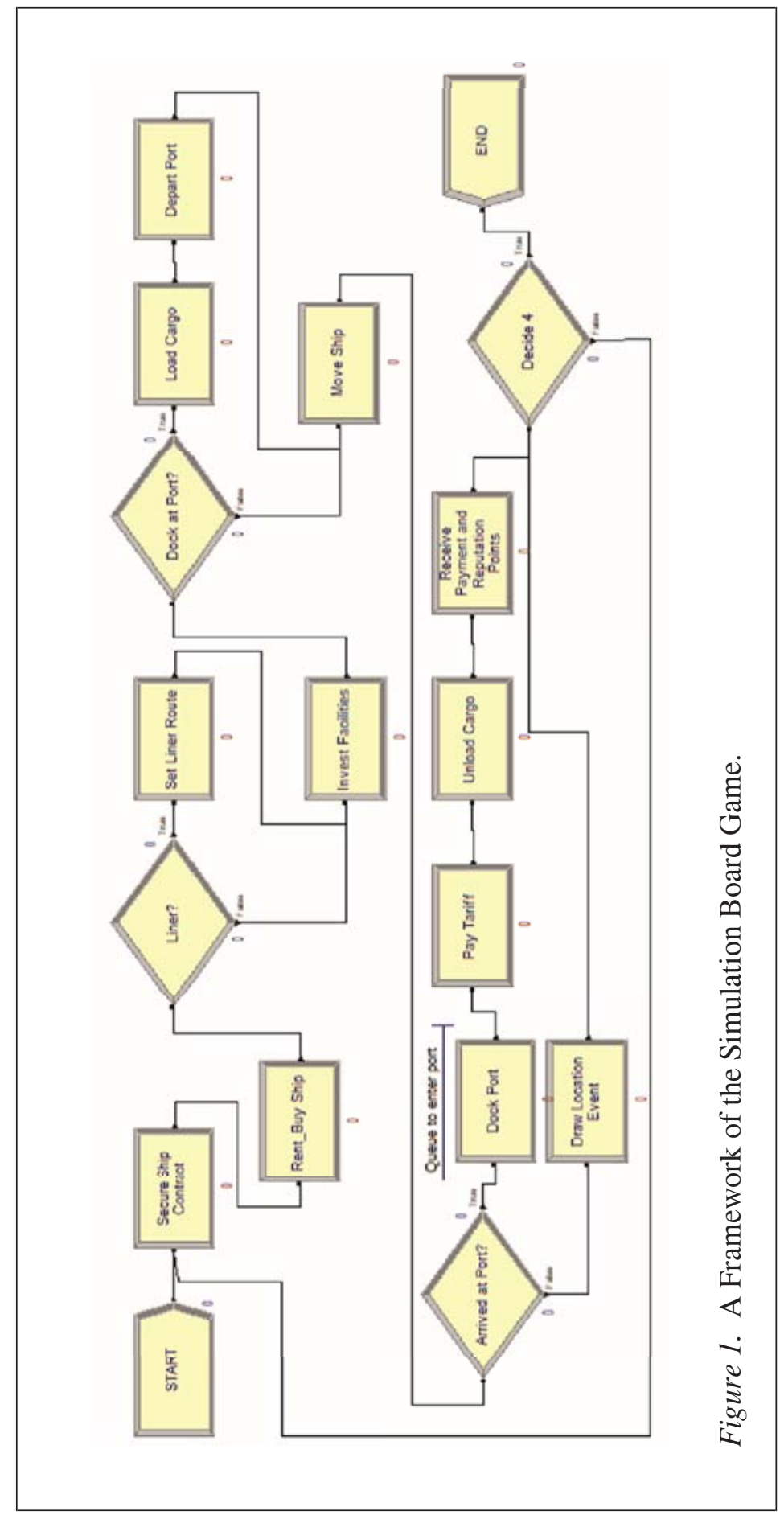


The gameplay is defined as the challenges that a game poses to the player and the actions that the player can perform in the game (Adams \& Dormans, 2012). The game mechanics or how the game presents its gameplay were identified and matched against course content. The selection of the game mechanics is important as it would reflect the actual processes that occur in a real life shipping operation. The selected game mechanics should be able to describe all processes they represent in brief. Then, game components such as main board, contract and ship cards, ship and status token and paper money were finalized to give a clear representation of all items used in the game. The game components are the tangible user interface that helps to connect the game and the players as they would immerse in the game session (Isoda et al., 2017).

Based on the simulation framework in Figure 1, there are fifteen key processes that can be grouped into three main phases in shipping operation or player turns in terms of gameplay. The alignment of the main phase, key processes and the task in ship management are presented in Table 2, while the alignment of the intended learning outcome of the shipping management course with the game developed is shown in Table 3.

\section{Table 2}

The Alignment of the Gameplay for the Board Game and the Task in Ship Management with the Intended Learning Outcome

\begin{tabular}{lll}
\hline $\begin{array}{c}\text { Player turn (main } \\
\text { phase) with intended } \\
\text { learning outcome }\end{array}$ & $\begin{array}{c}\text { Key processes in shipping } \\
\text { management }\end{array}$ & Task in ship management \\
\hline Planning phase & Rent or buy ship/ships & $\begin{array}{l}\text { Financial management, } \\
\text { crewing }\end{array}$ \\
$\begin{array}{l}\text { (Choose the best } \\
\text { means of shipping } \\
\text { methods in order ef- } \\
\text { ficiently manage the } \\
\text { company resources } \\
\text { to gain profit.) }\end{array}$ & Secure ship contracts & $\begin{array}{l}\text { Financial management, } \\
\text { procurement }\end{array}$ \\
& Determine liner or tramp service & $\begin{array}{l}\text { Technical management, } \\
\text { financial management }\end{array}$ \\
& Set liner routes & $\begin{array}{l}\text { Technical management, } \\
\text { quality and safety man- } \\
\text { agement }\end{array}$ \\
& Invest facility & Financial management \\
\hline
\end{tabular}




\begin{tabular}{|c|c|c|}
\hline $\begin{array}{l}\text { Player turn (main } \\
\text { phase) with intended } \\
\text { learning outcome }\end{array}$ & $\begin{array}{l}\text { Key processes in shipping } \\
\text { management }\end{array}$ & Task in ship management \\
\hline \multirow{6}{*}{$\begin{array}{l}\text { Operation phase } \\
\text { (Perform the process } \\
\text { of an efficient and } \\
\text { effective shipping } \\
\text { operation.) }\end{array}$} & Ship movement & \multirow{5}{*}{$\begin{array}{l}\text { Technical management, } \\
\text { quality and safety man- } \\
\text { agement }\end{array}$} \\
\hline & Ship dock at port & \\
\hline & Unload cargo & \\
\hline & Depart from port & \\
\hline & $\begin{array}{l}\text { Arrived at transit port or destina- } \\
\text { tion port }\end{array}$ & \\
\hline & Pay port tariff & Financial management \\
\hline \multirow{3}{*}{$\begin{array}{l}\text { Refresh phase } \\
\text { (Generalize the } \\
\text { outcome of the } \\
\text { operation from the } \\
\text { previous action as to } \\
\text { plan for next move.) }\end{array}$} & Unload destination cargo & $\begin{array}{l}\text { Technical management, } \\
\text { quality and safety man- } \\
\text { agement, procurement }\end{array}$ \\
\hline & $\begin{array}{l}\text { Received payment of successful } \\
\text { delivery }\end{array}$ & $\begin{array}{l}\text { Financial management, } \\
\text { procurement }\end{array}$ \\
\hline & $\begin{array}{l}\text { Draw event for location and pre- } \\
\text { pare for next round }\end{array}$ & Technical management \\
\hline
\end{tabular}

Table 3

The Alignment of the Intended Learning Outcome for A Shipping Management Course and the Activity in the Shipping Management Game that Players will Perform in Each Round

\begin{tabular}{ll}
\hline Intended learning outcome & Activity in the game \\
\hline $\begin{array}{l}\text { Differentiate between tramp } \\
\text { and liner services in maritime } \\
\text { logistics }\end{array}$ & Selecting the type of service for each ships. \\
$\begin{array}{l}\text { Demonstrate the ship services } \\
\text { in maritime logistics }\end{array}$ & $\begin{array}{l}\text { Harboring, loading, unloading and departing } \\
\text { rule for each type of ships. }\end{array}$ \\
$\begin{array}{l}\text { Organize the best route for } \\
\text { logistics and supply chain }\end{array}$ & $\begin{array}{l}\text { Moving ships across the map and selecting } \\
\text { the fastest and shortest route. }\end{array}$ \\
$\begin{array}{l}\text { Justify the logistics strategy in } \\
\text { order to fulfill demands }\end{array}$ & $\begin{array}{l}\text { Deciding on which port to harbors as } \\
\text { collecting more shipment contract or } \\
\text { completing shipment previous contract. }\end{array}$ \\
$\begin{array}{l}\text { Display good ethics in } \\
\text { performing logistics solution }\end{array}$ & $\begin{array}{l}\text { Following the rules of movement, } \\
\text { harboring, departure and obtaining shipment } \\
\text { contract in the game. }\end{array}$ \\
$\begin{array}{l}\text { Describe the process of an } \\
\text { effective and efficient logistics } \\
\text { operation }\end{array}$ & $\begin{array}{l}\text { Reflecting with the outcome of the } \\
\text { completed shipment contract - high profit } \\
\text { or low profit / high reputation or low } \\
\text { reputation gained. }\end{array}$ \\
\hline
\end{tabular}


The board game is played in multiple turns until the game end condition is met. A single game turn in the board game comprises three main phases which follow the order of planning, operation, and refresh phases. The phases from the gameplay are simplified from the comprehensive shipping operation which is focused on liner and tramp shipping. Therefore, players will be able to experience the processes and transactions that occur in a shipping management environment on a much smaller scale. In order to maintain focus and nurture intrinsic motivation towards the board game, the game challenge and players' skill must be well balanced. To meet the requirement, the game provides two types of challenges, i.e., challenge from the opponent and challenge created through the game. The game will challenge the players on how they decide to use their resources to best suit the ever-changing demand in the game, which is very dynamic. The destination contracts and port location as well as the continent will change every time the player plays the game. The other form of challenge is the opponent; the opponent will always try to compete for the best contracts which give the highest payment or highest reputation or both. Therefore, players need to plan carefully which options to choose, to compete in becoming the successful shipping company at the end of the game; thus the flow state of a player is well maintained during the game. The extrinsic rewards given in the game are reputation points and cash; rewards provide the players with satisfaction in the attainment of the game objective (Ali, Edwin, \& Tirimba, 2015; Njanja, Maina, Kibet, \& Njagi, 2013). Therefore, they will try to accept the challenge in completing the large contracts, hence becoming the leader in shipping operations.

\section{Design of the Shipping Management Game}

This study proposed the development of a shipping management board game from a simulation framework. This section provides an overview of the board game components.

\section{The Main Board}

The main board acts as the main user interface of the board game. It represents a game environment for all possible scenarios of the game. In the Shipping Management Game, the main board portrays the location of each port in a continent. The board game uses the 
modular board approach as its main board. This approach can ensure the re-playability of the board game, so players can maintain their interest after playing the game multiple times. The continent was built based on hexagonal tiles, consisting of land tiles and sea tiles. The arrangement of the hexagonal tiles can be randomized for each play session.

The hexagonal tiles were used because it offered more freedom in movement and less distortion for any movement. Hexagonal tiles have six neighbours, which enable more options towards movement in-between spaces. In comparison, only four neighbors are available in rectangular tiles, while triangular tiles have only three neighbors (Figure 2).

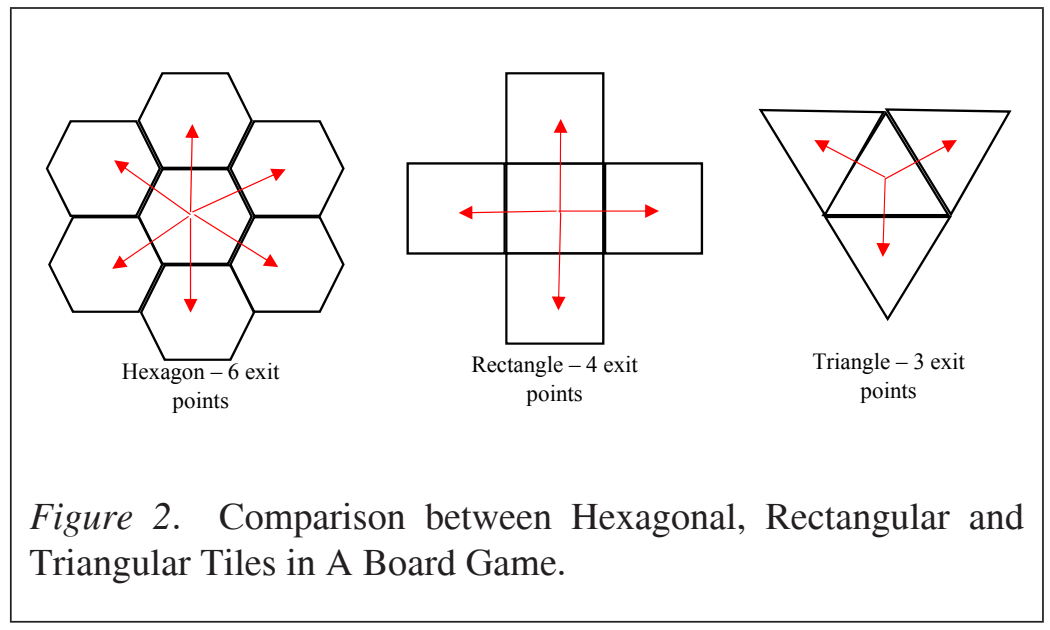

Having less neighbours means that the option of movement is limited. In terms of shipping, it replicates the vast sea area in the board game. It is important to replicate spaces that have as much neighbor of spaces available. In addition, the appearance of hexagonal tiles has its own appeal because it resembles the shape of a honeycomb. Hence, the hexagon shape was selected to be used as the main tile that constituted the modular shape of the continent for the board game.

\section{The Player Board}

The player board reflects the real-time status of the individual company throughout a play session (see Figure 3). It records the 
number of ships owned by a player, types of services offered by each ship, and contracts bound to shipping services. The player would be able to view the company status and make a reflection, and plan strategies for their next move when competing with their opponents. Meanwhile, a player may observe every competitor's company status since the player boards are made visible, simulating the status of real-life shipping companies listed on the stock exchange. Each player will gain feedback on what is happening around a continent, who the leading player is, and who their direct competitors are.

\section{The Ship Contract}

The ship contract is the resource that the players need to grab in order to make revenue, although they might make losses due to bad deployment of strategies. In each round of a game, a ship contract will be replenished in the main play area. The ship contract always displays its points and money that will be received if the contractor player manages to successfully deliver goods. No penalty will be received for late delivery, but the contractor players cannot collect bonuses when they are unable to achieve the duration of delivery.

\section{The Ship Movement}

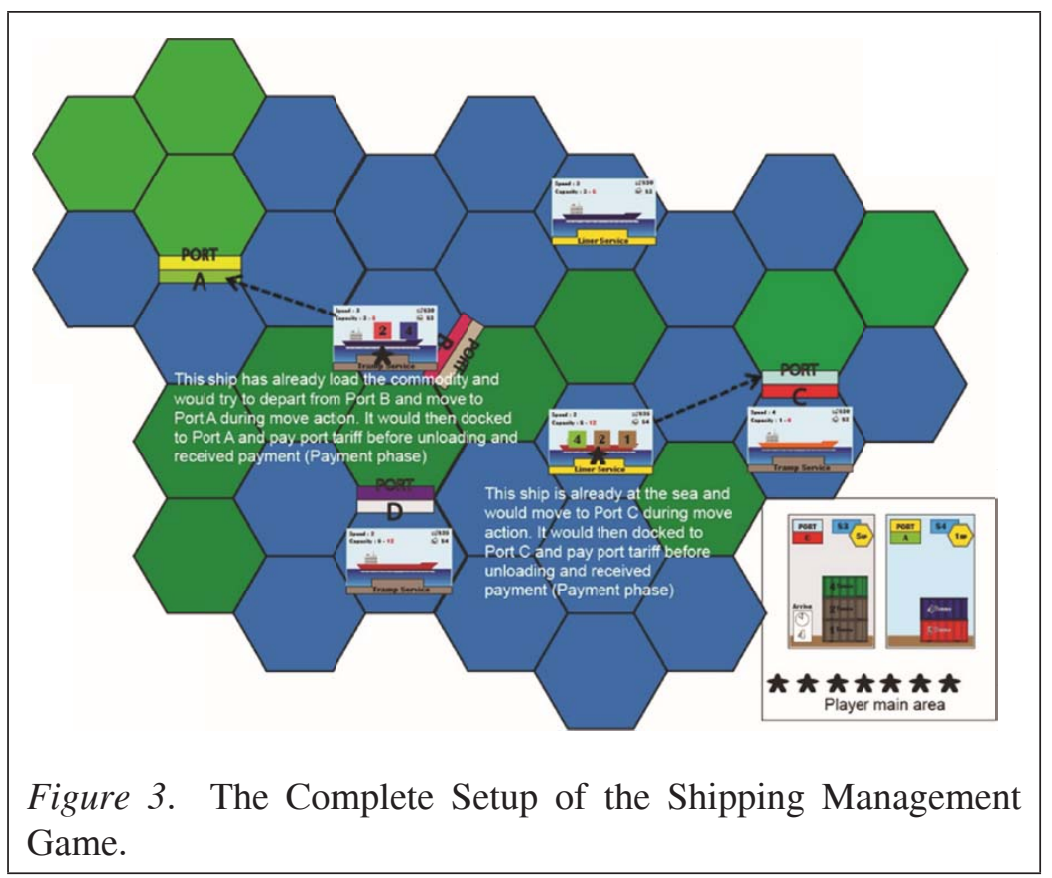


Ship tokens are used to mark the ownership, location, and movement of a ship throughout the game. The movement of the game follows the type of ships and services chosen by a player. The movement of ships is the core process of the game as players will try to deliver goods as stated in the contracts that they have secured. Players are only allowed to move their ship once during a single round. A round ends after all players complete moving their ships. After that, a new round will start and all ship movements will be replenished.

\section{Anatomy of Choice in the Shipping Management Game}

In order to contain players' flow in the game, a variety of choices are given to players as they plan their strategies to win the game. The anatomy of choice allows players to have numerous choices that would yield different results (Salen \& Zimmerman, 2004). Players will be able to choose a different strategy to counter their competitors' challenge in order to compete and win the game. Table 4 describes the anatomy of choice given to players in the Shipping Management Game.

Table 4

Anatomy of Choice for the Shipping Management Game

\begin{tabular}{|c|c|c|}
\hline Stage & Anatomy of a choice & Shipping Management Game \\
\hline 1 & $\begin{array}{l}\text { What happened before the } \\
\text { player was given the choice? }\end{array}$ & $\begin{array}{l}\text { Observing and analyzing how much capi- } \\
\text { tal in hand, ships owned, ship contracts } \\
\text { offered at each port, ship contract secured } \\
\text { at the current state, reputations gained and } \\
\text { specific event inflicted to the player }\end{array}$ \\
\hline 2 & $\begin{array}{l}\text { How is the possibility of choice } \\
\text { conveyed to the player? }\end{array}$ & $\begin{array}{l}\text { Planning for the possibility of ship owner- } \\
\text { ship, shipping services or securing more } \\
\text { ship contracts as to operate the shipping } \\
\text { company and route towards the destina- } \\
\text { tion. }\end{array}$ \\
\hline 3 & $\begin{array}{l}\text { How did the player make the } \\
\text { choice? }\end{array}$ & $\begin{array}{l}\text { Performing the action in each game } \\
\text { phase. }\end{array}$ \\
\hline 4 & $\begin{array}{l}\text { What is the result of the choice? } \\
\text { How it will affect future } \\
\text { choices? }\end{array}$ & $\begin{array}{l}\text { Placing ships in the main board as well } \\
\text { as opening the availability of new ship } \\
\text { contracts to be secured. }\end{array}$ \\
\hline 5 & $\begin{array}{l}\text { How is the result of the choice } \\
\text { conveyed to the player? }\end{array}$ & $\begin{array}{l}\text { Arranging ships on the main board and } \\
\text { players' area, obtaining revenue or losses } \\
\text { and completing ship contract and gaining } \\
\text { reputation points. }\end{array}$ \\
\hline
\end{tabular}




\section{FINDINGS}

\section{Results}

\section{Homogeneity Test}

The assumption of homogeneity of variance from the pre-test scores for both group was tested and satisfied via Levene's test, $F(1,71)$ $=.004, \mathrm{p}=.951$. Therefore, it was concluded that the data was homogeneous.

\section{Comparison of Performance for Overall Score}

A nonparametric test was performed to compare the effect of using the Shipping Management Game in post-learning activities for higher education. The Wilcoxon Signed Ranked test was used to measure any significant difference that exists between the time frame of the field testing, which was from $17^{\text {th }}$ September 2017 until $15^{\text {th }}$ December 2017. The alpha level was set at $\alpha=.05$.

Based on the results indicated in Table 5, on average, the scores of the experimental group (mean rank $=18.00, \mathrm{n}=35$ ) slightly exceeded those of the control group (mean rank $=17.80, \mathrm{n}=35),(\mathrm{p}=.000$, $\mathrm{p}<.05 ; \mathrm{Z}=-5.191)$. Although both groups showed a significant difference, the results clearly indicate that the experimental group obtained a higher score than the control group. Conclusively, the performance of students in the experimental group improved significantly after the game-based learning session, specifically through the use of the board game, the Shipping Management Game.

Table 5

Comparison of Pre-Test Scores and Post-Test Scores for the Control Group and the Experimental Group

\begin{tabular}{llccr}
\hline \multicolumn{1}{c}{ Ranks } & & & & \\
\hline & $\mathrm{N}$ & $\begin{array}{l}\text { Mean } \\
\text { Rank }\end{array}$ & Sum of Ranks \\
\hline Control group & $\begin{array}{l}\text { Negative } \\
\text { Ranks }\end{array}$ & $9^{\mathrm{a}}$ & 13.17 & 118.50 \\
\hline
\end{tabular}




\begin{tabular}{llccc}
\hline \multicolumn{1}{c}{ Ranks } & & & & \\
\hline Post-test score - & Positive Ranks & $23^{\mathrm{b}}$ & 17.80 & 409.50 \\
& & & & \\
& Ties & $6^{\mathrm{c}}$ & & .00 \\
& Total & 40 & & 630.00 \\
\hline Experimental group & Negative & $0^{\mathrm{a}}$ & .00 & \\
& Ranks & & & \\
Post-test score - Pre- & Positive Ranks & $35^{\mathrm{b}}$ & 18.00 & \\
test score & Ties & $0^{\mathrm{c}}$ & & \\
& Total & 35 & & \\
& & & & \\
\hline
\end{tabular}

\footnotetext{
a Post-test scores $<$ Pretest scores

b Post-test scores >

Pre-test scores

c Post-test scores $=$

Pre-test scores
}

Test Statistics ${ }^{\mathrm{b}}$

Z

Asymp.Sig.(2-tailed)

a Based on negative ranks.

b Wilcoxon Signed Ranks Test

\section{Comparison of Performance for Each Question}

Further analyses were done to identify differences in the performance on each question in the pre-test and post-test between the control group and the experimental group. The McNemar Test was used on nominal data with a dichotomous trait for either the question is answered right, or wrong. As for the result, the matched pairs of the student in this study involves pre-test and post-test and the control group and the experimental group.

\section{General Logistic (Sea Transportation) Questions (GLQ)}

The result of the McNemar test on hypotheses for the control group and the experimental group for the GLQ is presented in Table 6. All modes and medians were "Correct" for the control group, but no significant difference was found. On the other hand, 
a significant difference was found in the experimental group for the last two general logistic questions in the pre-test and the post-test. Specifically, the performance of the students in the experimental group slightly decreased, in which 23 students (out of 35) answered correctly in the pre-test for GLQ1 vs. 20 students in the post-test; 26 students answered correctly in the pre-test vs. 22 students in the posttest for GLQ2; 24 students answered correctly in the pre-test vs. 20 students in the post-test for GLQ3; 26 students answered correctly in the pre-test vs. 11 students in the post-test for GLQ4; and 15 students answered correctly in the pre-test vs. six students in the post-test for GLQ5. Nevertheless, only GLQ4 and GLQ5 showed a significant difference. Hence, there was not enough proof to indicate that there was a significant change in the learning of general logistics content using the board game. In conclusion, the intervention given to the experimental group, i.e., the Shipping Management board game, did not affect the students' performance significantly.

Table 6

Performance on the General Logistics Questions in the Pre-Test and Post-Test for the Control Group and the Experimental Group

\begin{tabular}{|c|c|c|c|c|c|c|c|c|}
\hline \multirow{2}{*}{ Group } & \multirow{2}{*}{ Test item } & & & \multicolumn{2}{|c|}{ Post-test } & \multirow[b]{2}{*}{ Mode } & \multirow[b]{2}{*}{ Median } & \multirow[b]{2}{*}{$\mathrm{p}$} \\
\hline & & & & Wrong & Correct & & & \\
\hline \multirow{10}{*}{$\begin{array}{l}\text { Within } \\
\text { control } \\
\text { group }\end{array}$} & \multirow{2}{*}{ GLQ1 } & \multirow{2}{*}{ Pre-test } & Wrong & 2 & 5 & \multirow{2}{*}{ Correct } & \multirow{2}{*}{ Correct } & \multirow{2}{*}{$1.000^{-}$} \\
\hline & & & Correct & 5 & 26 & & & \\
\hline & \multirow{2}{*}{ GLQ2 } & \multirow{2}{*}{ Pre-test } & Wrong & 0 & 1 & \multirow{2}{*}{ Correct } & \multirow{2}{*}{ Correct } & \multirow{2}{*}{$.625^{\mathrm{a}}$} \\
\hline & & & Correct & 3 & 34 & & & \\
\hline & \multirow{2}{*}{ GLQ3 } & \multirow{2}{*}{ Pre-test } & Wrong & 2 & 5 & \multirow{2}{*}{ Correct } & \multirow{2}{*}{ Correct } & \multirow{2}{*}{$.064^{\mathrm{a}}$} \\
\hline & & & Correct & 14 & 17 & & & \\
\hline & \multirow{2}{*}{ GLQ4 } & \multirow{2}{*}{ Pre-test } & Wrong & 3 & 6 & \multirow{2}{*}{ Correct } & \multirow{2}{*}{ Correct } & \multirow{2}{*}{$.332^{\mathrm{a}}$} \\
\hline & & & Correct & 11 & 18 & & & \\
\hline & \multirow{2}{*}{ GLQ5 } & \multirow{2}{*}{ Pre-test } & Wrong & 2 & 6 & \multirow{2}{*}{ Correct } & \multirow{2}{*}{ Correct } & \multirow{2}{*}{$.115^{\mathrm{a}}$} \\
\hline & & & Correct & 14 & 16 & & & \\
\hline \multirow{6}{*}{$\begin{array}{l}\text { Within } \\
\text { experimen- } \\
\text { tal group }\end{array}$} & \multirow{2}{*}{ GLQ1 } & \multirow{2}{*}{ Pre-test } & Wrong & 5 & 7 & \multirow{2}{*}{ Correct } & Correct & $600^{3}$ \\
\hline & & & Correct & 10 & 13 & & Conted & .029 \\
\hline & & & Wrong & 5 & 4 & & & \\
\hline & GLQ2 & Pre-test & Correct & 8 & 18 & Correct & Correct & $.388^{\mathrm{a}}$ \\
\hline & & & Wrong & 5 & 6 & & & \\
\hline & GLQJ & Pre-lest & Correct & 10 & 14 & Correct & Correct & .434 \\
\hline
\end{tabular}




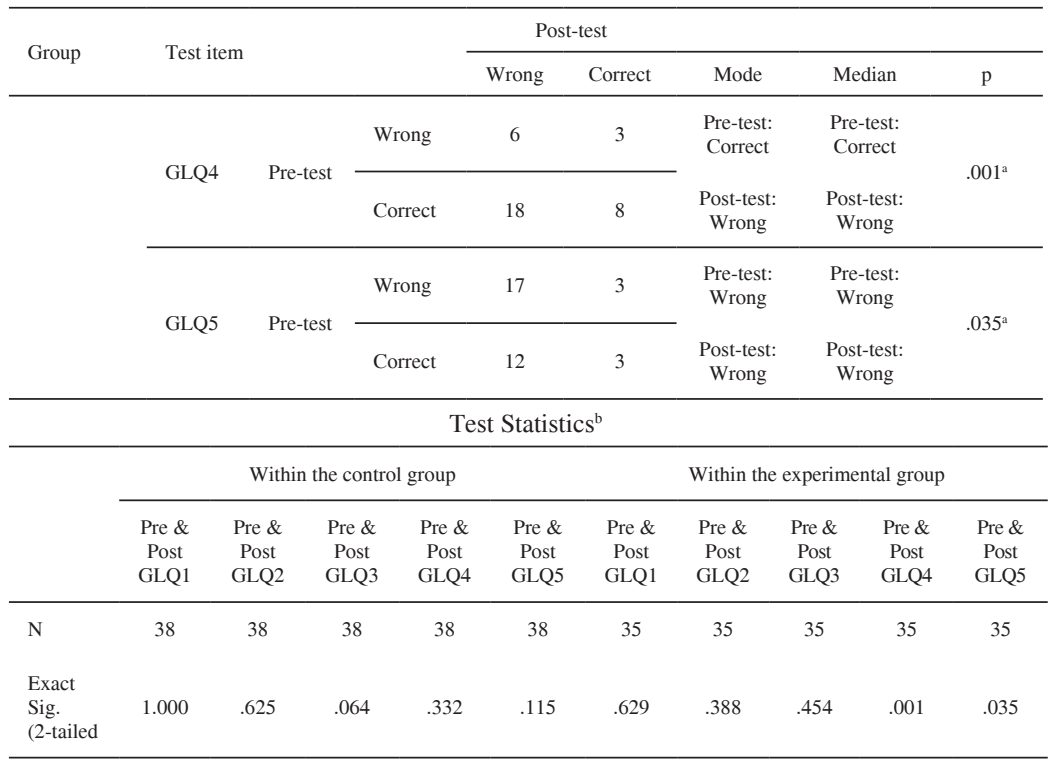

a Binomial distribution used.

b McNemar Test.

\section{Tramp Services Questions (TSQ)}

The result of the McNemar test on hypotheses for the control group and the experimental group for the TSQ is presented in Table 7. All modes and medians were "Wrong" for the control group but no significant difference was found. On the other hand, a significant difference was found in the experimental group for the last two tramp services questions in the pre-test and the post-test. In addition, the modes and medians in the experimental group changed from "Wrong" in the pre-test to "Correct" in the post-test. Specifically, the performance of the students in the experimental group slightly increased, in which 14 students (out of 35) answered correctly in the pre-test for TSQ1 vs. 19 students in the post-test; 12 students answered correctly in the pre-test vs. 25 students in the post-test for TSQ2; and seven students answered correctly in the pre-test vs. 23 students in the post-test for TSQ3. Only TSQ2 and TSQ3 showed a significant difference. Hence, there was adequate proof to indicate that there was a significant change towards learning about tramp services content using the board game. In conclusion, the intervention given to the experimental group did affect the students' score performance significantly. 
Table 7

Performance on the Tramp Services Questions in the Pre-Test and Post-Test for the Control Group and the Experimental Group

\begin{tabular}{|c|c|c|c|c|c|c|c|c|}
\hline \multirow{2}{*}{ Group } & \multirow{2}{*}{\multicolumn{2}{|c|}{ Test item }} & & \multicolumn{2}{|c|}{ Post-test } & \multirow[b]{2}{*}{ Mode } & \multirow[b]{2}{*}{ Median } & \multirow[b]{2}{*}{$\mathrm{p}$} \\
\hline & & & & Wrong & Correct & & & \\
\hline \multirow{6}{*}{$\begin{array}{l}\text { Within control } \\
\text { group }\end{array}$} & \multirow{2}{*}{ TSQ1 } & \multirow{2}{*}{ Pre-test } & Wrong & 17 & 3 & \multirow{2}{*}{ Wrong } & \multirow{2}{*}{ Wrong } & \multirow{2}{*}{$.057^{\mathrm{a}}$} \\
\hline & & & Correct & 11 & 7 & & & \\
\hline & \multirow{2}{*}{ TSQ2 } & \multirow{2}{*}{ Pre-test } & Wrong & 20 & 9 & \multirow{2}{*}{ Wrong } & \multirow{2}{*}{ Wrong } & \multirow{2}{*}{$.424^{\mathrm{a}}$} \\
\hline & & & Correct & 5 & 4 & & & \\
\hline & \multirow{2}{*}{ TSQ3 } & \multirow{2}{*}{ Pre-test } & Wrong & 24 & 7 & \multirow{2}{*}{ Wrong } & \multirow{2}{*}{ Wrong } & \multirow{2}{*}{$.774^{a}$} \\
\hline & & & Correct & 5 & 2 & & & \\
\hline \multirow{6}{*}{$\begin{array}{l}\text { Within } \\
\text { experimental } \\
\text { group }\end{array}$} & \multirow{2}{*}{ TSQ1 } & \multirow{2}{*}{ Pre-test } & Wrong & 12 & 9 & $\begin{array}{l}\text { Pre-test: } \\
\text { Wrong }\end{array}$ & $\begin{array}{c}\text { Pre- } \\
\text { test: } \\
\text { Wrong }\end{array}$ & \multirow{2}{*}{$.267^{\mathrm{a}}$} \\
\hline & & & Correct & 4 & 10 & $\begin{array}{l}\text { Post-test: } \\
\text { Correct }\end{array}$ & $\begin{array}{l}\text { Post- } \\
\text { test: } \\
\text { Correct }\end{array}$ & \\
\hline & \multirow{2}{*}{ TSQ2 } & \multirow{2}{*}{ Pre-test } & Wrong & 8 & 15 & $\begin{array}{l}\text { Pre-test: } \\
\text { Wrong }\end{array}$ & $\begin{array}{c}\text { Pre- } \\
\text { test: } \\
\text { Wrong }\end{array}$ & \multirow{2}{*}{, $002^{\mathrm{a}}$} \\
\hline & & & Correct & 2 & 10 & $\begin{array}{l}\text { Post-test: } \\
\text { Correct }\end{array}$ & $\begin{array}{l}\text { Post- } \\
\text { test: } \\
\text { Correct }\end{array}$ & \\
\hline & \multirow{2}{*}{ TSQ3 } & \multirow{2}{*}{ Pre-test } & Wrong & 11 & 17 & $\begin{array}{l}\text { Pre-test: } \\
\text { Wrong }\end{array}$ & $\begin{array}{c}\text { Pre- } \\
\text { test: } \\
\text { Wrong }\end{array}$ & \multirow{2}{*}{$.000^{\mathrm{a}}$} \\
\hline & & & Correct & 1 & 6 & $\begin{array}{l}\text { Post-test: } \\
\text { Correct }\end{array}$ & $\begin{array}{l}\text { Post- } \\
\text { test: } \\
\text { Correct }\end{array}$ & \\
\hline
\end{tabular}

\begin{tabular}{|c|c|c|c|c|c|c|}
\hline \multicolumn{7}{|c|}{ Test Statistics ${ }^{b}$} \\
\hline & \multicolumn{3}{|c|}{ Within the control group } & \multicolumn{3}{|c|}{ Within the experimental group } \\
\hline & $\begin{array}{c}\text { Pre \& Post } \\
\text { TSQ1 }\end{array}$ & $\begin{array}{c}\text { Pre \& Post } \\
\text { TSQ2 }\end{array}$ & $\begin{array}{c}\text { Pre \& } \\
\text { Post } \\
\text { TSQ3 }\end{array}$ & $\begin{array}{c}\text { Pre \& } \\
\text { Post } \\
\text { TSQ1 }\end{array}$ & $\begin{array}{c}\text { Pre \& } \\
\text { Post } \\
\text { TSQ2 }\end{array}$ & $\begin{array}{l}\text { Pre \& Post } \\
\text { TSQ3 }\end{array}$ \\
\hline $\mathrm{N}$ & 38 & 38 & 38 & 35 & 35 & 35 \\
\hline Exact Sig. (2-tailed & .057 & .424 & .774 & .267 & .002 & .000 \\
\hline
\end{tabular}

a Binomial distribution used.

b McNemar Test.

\section{Liner Services Questions (LSQ)}

The result of the McNemar test on hypotheses for the control group and the experimental group for the LSQ is presented in Table 8. All modes and medians were "Wrong" for the control group but only LSQ3 showed a significant difference. Meanwhile, a significant difference was found in the experimental group for all liner services 
questions in the pre-test and the post-test. Additionally, the modes and medians in the experimental group change from "Wrong" in the pre-test to "Correct" in the post-test. In detail, the performance of the students in the experimental group increased significantly, in which 10 students (out of 35) answered correctly in the pre-test for LSQ1 vs. 24 students in the post-test; four students answered correctly in the pre-test vs. 25 students in the post-test for LSQ2; six students answered correctly in the pre-test vs. 22 students in the post-test for TSQ3; and three students answered correctly in the pre-test vs 24 students in the post-test for LSQ4. The results of the McNemar test indicate that all liner services questions showed a significant difference. Hence, there was sufficient proof to indicate that there was a significant change towards learning about liner services content using the board game. In conclusion, the intervention given to the experimental group, which is the board game, affected the students' performance significantly.

Table 8

Performance on the Liner Services Questions in the Pre-Test and Post-Test for the Control Group and the Experimental Group

\begin{tabular}{|c|c|c|c|c|c|c|c|c|}
\hline \multirow{2}{*}{ Group } & \multirow{2}{*}{ Test item } & & & \multicolumn{2}{|c|}{ Post-test } & \multirow[b]{2}{*}{ Mode } & \multirow[b]{2}{*}{ Median } & \multirow[b]{2}{*}{$\mathrm{p}$} \\
\hline & & & & Wrong & Correct & & & \\
\hline \multirow{8}{*}{$\begin{array}{l}\text { Within } \\
\text { control } \\
\text { group }\end{array}$} & \multirow{2}{*}{$\begin{array}{l}\text { Liner } \\
\text { services } \\
\text { question } \\
1\end{array}$} & \multirow{2}{*}{$\begin{array}{l}\text { Pre- } \\
\text { test }\end{array}$} & Wrong & 24 & 8 & \multirow[b]{2}{*}{ Wrong } & \multirow[b]{2}{*}{ Wrong } & \multirow[b]{2}{*}{$.388^{\mathrm{a}}$} \\
\hline & & & Correct & 4 & 2 & & & \\
\hline & \multirow{2}{*}{$\begin{array}{l}\text { Liner } \\
\text { services } \\
\text { question } \\
2\end{array}$} & \multirow[b]{2}{*}{$\begin{array}{l}\text { Pre- } \\
\text { test }\end{array}$} & Wrong & 23 & 8 & \multirow[b]{2}{*}{ Wrong } & \multirow[b]{2}{*}{ Wrong } & \multirow[b]{2}{*}{$.227^{a}$} \\
\hline & & & Correct & 3 & 4 & & & \\
\hline & \multirow{2}{*}{$\begin{array}{l}\text { Liner } \\
\text { services } \\
\text { question } \\
3\end{array}$} & \multirow[b]{2}{*}{$\begin{array}{l}\text { Pre- } \\
\text { test }\end{array}$} & Wrong & 29 & 9 & \multirow[b]{2}{*}{ Wrong } & \multirow[b]{2}{*}{ Wrong } & \multirow[b]{2}{*}{$.004^{\mathrm{a}}$} \\
\hline & & & Correct & 0 & 0 & & & \\
\hline & \multirow{2}{*}{$\begin{array}{l}\text { Liner } \\
\text { services } \\
\text { question } \\
4\end{array}$} & \multirow[b]{2}{*}{$\begin{array}{l}\text { Pre- } \\
\text { test }\end{array}$} & Wrong & 30 & 7 & \multirow[b]{2}{*}{ Wrong } & \multirow[b]{2}{*}{ Wrong } & \multirow[b]{2}{*}{$.070^{\mathrm{a}}$} \\
\hline & & & Correct & 1 & 0 & & & \\
\hline \multirow{2}{*}{$\begin{array}{l}\text { Within } \\
\text { experimental } \\
\text { group }\end{array}$} & \multirow{2}{*}{$\begin{array}{l}\text { Liner } \\
\text { services } \\
\text { question } \\
1\end{array}$} & \multirow{2}{*}{$\begin{array}{l}\text { Pre- } \\
\text { test }\end{array}$} & Wrong & 8 & 17 & $\begin{array}{c}\text { Pre- } \\
\text { test: } \\
\text { Wrong }\end{array}$ & $\begin{array}{c}\text { Pre-test: } \\
\text { Wrong }\end{array}$ & \multirow{2}{*}{$.003^{\mathrm{a}}$} \\
\hline & & & Correct & 3 & 7 & $\begin{array}{l}\text { Post- } \\
\text { test: } \\
\text { Correct }\end{array}$ & $\begin{array}{l}\text { Post- } \\
\text { test: } \\
\text { Correct }\end{array}$ & \\
\hline
\end{tabular}




\begin{tabular}{|c|c|c|c|c|c|c|c|c|}
\hline \multirow{2}{*}{ Group } & \multirow{2}{*}{ Test item } & & & \multicolumn{2}{|c|}{ Post-test } & \multirow[b]{2}{*}{ Mode } & \multirow[b]{2}{*}{ Median } & \multirow[b]{2}{*}{$\mathrm{p}$} \\
\hline & & & & Wrong & Correct & & & \\
\hline & \multirow{2}{*}{$\begin{array}{l}\text { Liner } \\
\text { services } \\
\text { question } \\
2\end{array}$} & \multirow{2}{*}{$\begin{array}{l}\text { Pre- } \\
\text { test }\end{array}$} & Wrong & 10 & 21 & $\begin{array}{c}\text { Pre- } \\
\text { test: } \\
\text { Wrong }\end{array}$ & $\begin{array}{c}\text { Pre-test: } \\
\text { Wrong }\end{array}$ & \multirow{2}{*}{, $000^{\mathrm{a}}$} \\
\hline & & & Correct & 0 & 4 & $\begin{array}{l}\text { Post- } \\
\text { test: } \\
\text { Correct }\end{array}$ & $\begin{array}{l}\text { Post- } \\
\text { test: } \\
\text { Correct }\end{array}$ & \\
\hline & \multirow{2}{*}{$\begin{array}{l}\text { Liner } \\
\text { services } \\
\text { question } \\
3\end{array}$} & \multirow{2}{*}{$\begin{array}{l}\text { Pre- } \\
\text { test }\end{array}$} & Wrong & 11 & 18 & $\begin{array}{c}\text { Pre- } \\
\text { test: } \\
\text { Wrong }\end{array}$ & $\begin{array}{c}\text { Pre-test: } \\
\text { Wrong }\end{array}$ & \multirow{2}{*}{$.000^{\mathrm{a}}$} \\
\hline & & & Correct & 2 & 4 & $\begin{array}{l}\text { Post- } \\
\text { test: } \\
\text { Correct }\end{array}$ & $\begin{array}{c}\text { Post- } \\
\text { test: } \\
\text { Correct }\end{array}$ & \\
\hline & \multirow{2}{*}{$\begin{array}{l}\text { Liner } \\
\text { services } \\
\text { question } \\
4\end{array}$} & \multirow{2}{*}{$\begin{array}{l}\text { Pre- } \\
\text { test }\end{array}$} & Wrong & 11 & 21 & $\begin{array}{c}\text { Pre- } \\
\text { test: } \\
\text { Wrong }\end{array}$ & $\begin{array}{l}\text { Pre-test: } \\
\text { Wrong }\end{array}$ & \multirow{2}{*}{$.000^{\mathrm{a}}$} \\
\hline & & & Correct & 0 & 3 & $\begin{array}{l}\text { Post- } \\
\text { test: } \\
\text { Correct }\end{array}$ & $\begin{array}{l}\text { Post- } \\
\text { test: } \\
\text { Correct }\end{array}$ & \\
\hline
\end{tabular}

\begin{tabular}{lcccccccc}
\hline \multicolumn{10}{c}{ Test Statistics $^{\mathrm{b}}$} \\
\hline & \multicolumn{1}{c}{ Within the control group } & \multicolumn{3}{c}{ Within the experimental group } \\
\cline { 2 - 9 } & $\begin{array}{r}\text { Pre \& } \\
\text { Post } \\
\text { LSQ1 }\end{array}$ & $\begin{array}{r}\text { Pre \& } \\
\text { Post } \\
\text { LSQ2 }\end{array}$ & $\begin{array}{c}\text { Pre \& } \\
\text { Post } \\
\text { LSQ3 }\end{array}$ & $\begin{array}{c}\text { Pre \& } \\
\text { Post } \\
\text { LSQ4 }\end{array}$ & $\begin{array}{c}\text { Pre \& } \\
\text { Post } \\
\text { LSQ1 }\end{array}$ & $\begin{array}{c}\text { Pre \& } \\
\text { Post } \\
\text { LSQ2 }\end{array}$ & $\begin{array}{c}\text { Pre \& } \\
\text { Post } \\
\text { LSQ3 }\end{array}$ & $\begin{array}{c}\text { Pre \& } \\
\text { Post } \\
\text { LSQ4 }\end{array}$ \\
\hline $\mathrm{N}$ & 38 & 38 & 38 & 38 & 35 & 35 & 35 & 35 \\
$\begin{array}{l}\text { Exact Sig. } \\
\text { (2-tailed }\end{array}$ & .388 & .227 & .004 & .070 & .003 & .000 & .000 & .000 \\
\hline
\end{tabular}

a Binomial distribution used.

b McNemar Test.

\section{Tramp and Liner Services Questions (T\&LSQ)}

The result of the McNemar test on hypotheses for the control group and the experimental group for the T\&LSQ is presented in Table 9. For the control group, all modes and medians were "Wrong" and a significant difference was found for all tramp and liner service questions. On the other hand, a significant difference was found in the experimental group for all liner services questions in the pre-test and the post-test. In addition, the modes and medians in the experimental group changed from "Wrong" in the pre-test to "Correct" in the post-test for T\&LSQ1 and T\&LSQ2. In detail, the performance of the students in the experimental group increased significantly, in which two students (out of 35) answered correctly in the pre-test 
for T\&LSQ 1 vs. 24 students in the post-test; one student answered correctly in the pre-test vs. 26 students in the post-test for T\&LSQ 2; and two students answered correctly in the pre-test vs. 12 students in the post-test for T\&LSQ3. The result of the McNemar test indicates that all tramp and liner services questions show a significant difference for the experimental group. Although both control group and experimental group showed a significant difference in the tramp and liner service questions, the result provides clear evidence that the experimental group performed better in test scores thana the control group. Hence there was enough proof to indicate that there was a significant change in the learning of liner services content using the board game. In conclusion, the intervention affected the experimental group's performance significantly.

Table 9

Performance on the Tramp and Liner Services Questions in the Pre-Test and Post-test for the Control Group and the Experimental Group

\begin{tabular}{|c|c|c|c|c|c|c|c|c|}
\hline \multirow{2}{*}{ Group } & \multirow{2}{*}{\multicolumn{2}{|c|}{ Test item }} & & \multicolumn{2}{|c|}{ Post-test } & \multirow[b]{2}{*}{ Mode } & \multirow[b]{2}{*}{ Median } & \multirow[b]{2}{*}{$\mathrm{P}$} \\
\hline & & & & Wrong & Correct & & & \\
\hline \multirow{6}{*}{$\begin{array}{l}\text { Within } \\
\text { control group }\end{array}$} & \multirow{2}{*}{$\begin{array}{l}\text { T\& } \\
\text { LSQ1 }\end{array}$} & \multirow{2}{*}{$\begin{array}{l}\text { Pre- } \\
\text { test }\end{array}$} & Wrong & 26 & 12 & \multirow{2}{*}{ Wrong } & \multirow{2}{*}{ Wrong } & \multirow{2}{*}{$.000^{\mathrm{a}}$} \\
\hline & & & Correct & 0 & 0 & & & \\
\hline & \multirow{2}{*}{$\begin{array}{l}\text { T\& } \\
\text { LSQ2 }\end{array}$} & \multirow{2}{*}{$\begin{array}{l}\text { Pre- } \\
\text { test }\end{array}$} & Wrong & 27 & 10 & \multirow{2}{*}{ Wrong } & \multirow{2}{*}{ Wrong } & \multirow{2}{*}{$.012^{\mathrm{a}}$} \\
\hline & & & Correct & 1 & 0 & & & \\
\hline & \multirow{2}{*}{$\begin{array}{l}\text { T\& } \\
\text { LSQ3 }\end{array}$} & \multirow{2}{*}{$\begin{array}{l}\text { Pre- } \\
\text { test }\end{array}$} & Wrong & 26 & 12 & \multirow{2}{*}{ Wrong } & \multirow{2}{*}{ Wrong } & \multirow{2}{*}{$.000^{\mathrm{a}}$} \\
\hline & & & Correct & 0 & 0 & & & \\
\hline \multirow{6}{*}{$\begin{array}{l}\text { Within } \\
\text { experimental } \\
\text { group }\end{array}$} & \multirow{2}{*}{$\begin{array}{l}\text { T\& } \\
\text { LSQ1 }\end{array}$} & \multirow{2}{*}{$\begin{array}{l}\text { Pre- } \\
\text { test }\end{array}$} & Wrong & 11 & 22 & \multirow{2}{*}{$\begin{array}{c}\text { Pre- } \\
\text { test: } \\
\text { Wrong } \\
\text { Post- } \\
\text { test: } \\
\text { Correct }\end{array}$} & $\begin{array}{l}\text { Pre-test: } \\
\text { Wrong }\end{array}$ & \multirow{2}{*}{$.000^{\mathrm{a}}$} \\
\hline & & & Correct & 0 & 2 & & $\begin{array}{l}\text { Post- } \\
\text { test: } \\
\text { Correct }\end{array}$ & \\
\hline & \multirow{2}{*}{$\begin{array}{l}\text { T\& } \\
\text { LSQ2 }\end{array}$} & \multirow{2}{*}{$\begin{array}{l}\text { Pre- } \\
\text { test }\end{array}$} & Wrong & 9 & 25 & \multirow{2}{*}{$\begin{array}{c}\text { Pre- } \\
\text { test: } \\
\text { Wrong } \\
\text { Post- } \\
\text { test: } \\
\text { Correct }\end{array}$} & $\begin{array}{l}\text { Pre-test: } \\
\text { Wrong }\end{array}$ & \multirow{2}{*}{, $000^{\mathrm{a}}$} \\
\hline & & & Correct & 0 & 1 & & $\begin{array}{l}\text { Post- } \\
\text { test: } \\
\text { Correct }\end{array}$ & \\
\hline & \multirow{2}{*}{$\begin{array}{l}\text { T\& } \\
\text { LSQ3 }\end{array}$} & \multirow{2}{*}{$\begin{array}{l}\text { Pre- } \\
\text { test }\end{array}$} & Wrong & 22 & 11 & \multirow{2}{*}{ Wrong } & \multirow{2}{*}{ Wrong } & \multirow{2}{*}{$.006^{\mathrm{a}}$} \\
\hline & & & Correct & 1 & 1 & & & \\
\hline
\end{tabular}


Test Statistics ${ }^{b}$

\begin{tabular}{lcccccc}
\hline & \multicolumn{3}{c}{ Within the control group } & \multicolumn{2}{c}{ Within the experimental group } \\
\cline { 2 - 6 } & $\begin{array}{c}\text { Pre \& } \\
\text { Post } \\
\text { T\&LSQ1 }\end{array}$ & $\begin{array}{c}\text { Pre \& Post } \\
\text { T\&LSQ2 }\end{array}$ & $\begin{array}{c}\text { Pre \& } \\
\text { Post } \\
\text { T\&LSQ3 }\end{array}$ & $\begin{array}{c}\text { Pre \& } \\
\text { Post } \\
\text { T\&LSQ1 }\end{array}$ & $\begin{array}{c}\text { Pre \& } \\
\text { Post } \\
\text { T\&LSQ2 }\end{array}$ & $\begin{array}{c}\text { Pre \& } \\
\text { Post } \\
\text { T\&LSQ3 }\end{array}$ \\
\hline $\mathrm{N}$ & 38 & 38 & 38 & 35 & 35 & 35 \\
$\begin{array}{l}\text { Exact Sig. } \\
\text { (2-tailed }\end{array}$ & .000 & .012 & .000 & .000 & .000 & .006 \\
\hline
\end{tabular}

a Binomial distribution used.

b McNemar Test.

\section{DISCUSSION}

The Shipping Management Game was developed using a simulation framework from the context of liner and tramp shipping. However, as a framework it is much simpler than shipping operations in reality. In fact, it was designed based on intended learning outcome. For instance, the board game does not consider the shipping policy in detail, the detailed process of shipping contract, warehousing and safety procedures in shipping operations. It only considers the fundamental elements of how to connect the shipping line, ports and its consignee and supplier. In general, the board game does include the key processes of liner and tramp shipping, which considers the type of ships, shipping services, liner route, home ports, rules of docking, flag discrimination and a few minor policies. In addition, the aggregation of points to determine the winner is necessary to maintain the characteristics of a board game. Although reputation points were given for each successful delivery/completion of the contract, they were not the only points a player can obtain in the game. The board game also considers the asset and money the player has obtained throughout the game session, thus making a comprehensive assessment of players' achievement during the gameplay or while the players managed their shipping company.

There are three main characteristics of the game that reflect the intended learning outcome for the Shipping Management course. The first characteristic is the difference in tramp and liner shipping services and how each operates in the simulation of the game. Players are able to understand the advantage and drawback of both services by completing the contract bound to the ships. Furthermore, players also might strategize to exploit the best type of ship 
services to compete with other players. The second characteristic is the movement of the ships managed by the players reflects the management of operations of ships. Within this activity, players would be able to plan the optimal route for their ship to pick up and deliver contracts, which are able to provide them with the highest return and reputation points. This exercise provides players with a transparent experimentation of route selection for ship travels. The third characteristic is the revenue and loss gains as well as the reputation points from the completed shipment. Through hands-on practice, players should be able to monitor the flow of cash and the reputation points collected for their company. Hence, players would understand their company status before making further investments.

In a nutshell, the board game has been designed to be played by three to five players where every player would act as a manager in a different shipping company competing for fame and reputation as well as capital in order to become a prestigious shipping company. In the future, the game will be designed to include a scenario-based task which makes it possible for the game to be played solo or with a dedicated number of players. The construction of the task will be either based on real-world or fictional scenario so as to test the players' knowledge. This scenario-based task will be added in the campaign play of the shipping company. Hence, there will be a dominant strategy on how to solve the task, which makes every action done during the gameplay more critical and tense. The addition of the campaign mode is also able to create feedback for players as they will be able to reflect on the wrong move that they made when they were not successful in solving the task. Consequently, it will be the opposite on the gameplay style which was proposed, which is more towards a simulation sandbox game. A simulation sandbox game is different in terms of the freedom of the players to make decisions in the game and reflect its consequences (Olson, 2010). Therefore, the simulation board game does not have a dominant strategy for winning the game; the game lets the players explore all possible actions where there is no right or wrong answer. Only the players would able to judge it on its own based on the main objective that they would try to achieve.

The result of the field testing for the board game 'The Shipping Management Game' was consistent with the literature (Eterovic \& Santos, 2013; Khan \& Pearce, 2015; Liu, 2016; McCarthy, 
2014; Rastegarpour \& Marashi, 2012; Wait \& Frazer, 2018) which highlighted the effectiveness in using game-based learning for the achievement of participants. Although the results did not support the effectiveness of empowering learning of general logistics in the context of sea transportation, it did provide a slight improvement from the normal post-learning activities. Both groups showed a significant difference in the last group of questions tested in the field study. The scenario is true in regards to both groups that had undergone a series of separate medium of post-learning activities. However, the results demonstrated that the experimental group performed slightly better than the control group. Therefore, it supported the usage of The Shipping Management Game as a medium for post-learning activities on shipping management.

\section{CONCLUSION}

This study proposed a framework of using board games as a simulation tool for learning shipping management at tertiary education level. A board game framework was developed based on the syllabus of an undergraduate shipping management course, focusing on tramp and liner shipping services. The design of the board game represents a comprehensive shipping operation that occurs in the real world.

The use of a board game in game-based learning practice presents students with the opportunity to visualize the theories of logistics being taught in lectures. Furthermore, the game-based learning practice triggers learning by doing, affording knowledge discovery among the students in a non-threatening environment. The board game has the capability to reduce the time for players to learn shipping management while nurturing and fostering their knowledge of real-life applications on a smaller scale. When the board game is played repeatedly, students would be able to try out as many possible moves and strategies as possible, simulating the actual scenarios that can occur in authentic shipping management. This, in turn, might foster logistic innovation among the students in the long run due to the possibility and combination of strategies to overcome problems and challenges throughout the game. Even though the main theme of the board game is shipping management, the simulation framework used to develop the game is generic and can be applied to develop almost any other logistics management game. 


\section{ACKNOWLEDGEMENT}

The conduct of this study has been supported by the Malaysia Ministry of Higher Education under the Skim Latihan Kakitangan Akademik dan Pentadbiran (Academic and Administrative Staff Training Scheme), Sultan Idris Education University and Universiti Utara Malaysia.

\section{REFERENCES}

Adams, E., \& Dormans, J. (2012). Game mechanics: Advanced game design. California: New Riders Games.

Ahmad, P. A., Radzi, S. H. M., \& Radzi, S. I. M. (2017). Mengukur keberkesanan penggunaan board game dalam pembelajaran asas operasi matematik. In 3rd International Conference on Research and Innovation.

Ali, A. A., Edwin, O., \& Tirimba, O. I. (2015). Analysis of extrinsic rewards and employee satisfaction: Case of Somtel company in Somaliland. International Journal of Business Management \& Economic Research, 6(6), 417-435.

Allate, B. M. (2015). Shipping management and logistics innovation: Key factors for success. The International Journal of Management Science and Business Administration, 2(1), 51-56. https://doi.org/10.18775/ ijmsba.1849-5664-5419.2014.21.1005

Bagwan, F., Bias, D., Ahuja, R., \& Bagde, L. (2016). Tangible user interface based descriptor for appliances. International Journal of Research in Advent Technology, (March), 179185.

Canning, T. (2013). Shipping forecast [Board game]. The Game Crafter.

Cherif, A. H., Jedlicka, D., Verma, S., Uddin, K., \& Movahedzadeh, F. (2017). Brain Talking: Classroom activity to engage students in deep and meaningful learning. Journal of Education and Practice, 8(32), 156-174.

Cushman-Roisin, B., Rice, N. J., III, \& Moldaver, M. A. (2000). A simulation tool for industrial ecology - Creating a board game. Journal of Industrial Ecology, 3(4), 131-144.

Dahlin, J., Larsson, P., \& Erlich, C. (2013). The use of board games in the engineering education for the purpose of stimulating peer participation in lecture theatre discussions. Engineering Education for Sustainable Development, 1, 1-9. 
de Freitas, S. (2008). Emerging trends in serious games and virtual worlds. Emerging Technologies for Learning, 3(March), 5872.

De Lope, R. P., Medina-Medina, N., Paderewski, P., \& GutierrezVela, F. L. (2015). Design methodology for educational games based on interactive screenplays. In CEUR Workshop Proceedings (Vol. 1394, pp. 90-101).

Eterovic, A., \& Santos, C. M. D. (2013). Teaching the role of mutation in evolution by means of a board game. Evolution: Education and Outreach, 6(22), 1-10.

Huang, A., \& Levinson, D. (2012). To game or not to game. Transportation Research Record: Journal of the Transportation Research Board, 2307(1), 141-149. https:// doi.org/10.3141/2307-15

Hung, H.-C., Young, S. S.-C., \& Lin, C.-P. (2013). No student left behind: A collaborative and competitive game-based learning environment to reduce the achievement gap of EFL students in Taiwan. Technology, Pedagogy and Education, 24(1), 3549. https://doi.org/10.1080/1475939X.2013.822412

Isoda, K., Sueyoshi, K., Miyamoto, R., Nishimura, Y., Ikeda, Y., Hisanaga, I., Higuchi, S. (2017). Tangible user interface and mu rhythm suppression: The effect of user interface on the brain activity in its operator and observer. Applied Sciences, 7(347), 1-12. https://doi.org/10.3390/app7040347

Jahn, C., \& Bussow, T. (2013). Best practice ship management. Germanischer Lloyd SE.

Jong, M. S., \& Shang, J. (2015). Impeding phenomena emerging from students' constructivist online game-based learning process: Implications for the importance of teacher facilitation. Journal of Educational Technology \& Society, 18(2), 262283. Retrieved from http://proxy1.ncu.edu/login?url=http:// search.ebscohost.com/login.aspx?direct=true $\& d b=$ ehh $\& A N$ $=102557874 \&$ site $=$ eds-live

Khan, A., \& Pearce, G. (2015). A study into the effects of a board game on flow in undergraduate business students. The International Journal of Management Education, 13(3), 193201.

Lennon, J. L., \& Coombs, D. W. (2007). The utility of a board game for dengue hemorrhagic fever health education. Health Education, 107(3), 290-306.

Li, Q. (2010). Digital game building: Learning in a participatory culture. Educational Research, 52(4), 427-443. https://doi.or $\mathrm{g} / 10.1080 / 00131881.2010 .524752$ 
Liu, T.-Y. (2016). Using educational games and simulation software in a computer science course: Learning achievements and student flow experiences. Interactive Learning Environments, 24(4), 724-744. https://doi.org/10.1080/10494820.2014.917 109

McCarthy, M. M. (2014). The role of games and simulations to teach abstract concepts of anarchy, cooperation, and conflict in world politics. Journal of Political Science Education, 10(4), 400-413. https://doi.org/10.1080/15512169.2014.947417

Minnery, J., \& Searle, G. (2012). The effectiveness of computer games for planning education: A SimCity case study. In Australia and New Zealand Association of Planning Schools Conference, 142. La Trobe University.

Njanja, L. W., Maina, R. N., Kibet, L. K., \& Njagi, K. (2013). Effect of reward on employee performance: A case of Kenya Power and Lighting Company Ltd., Nakuru, Kenya. International Journal of Business and Management, 8(21), 41-49. https:// doi.org/10.5539/ijbm.v8n21p41

Nunohiro, E., Matsushita, K., Mackin, K. J., \& Ohshiro, M. (2013). Development of game-based learning features in programming learning support system. Artificial Life and Robotics, 17(3-4), 373-377. https://doi.org/10.1007/s10015-012-0073-x

Ober, C. P. (2017). Examination outcomes following use of card games for learning radiographic image quality in veterinary medicine. Journal of Veterinary Medical Education, 45(1), 140-144. https://doi.org/10.3138/jvme.0916-146r

Olson, C. K. (2010). Children's motivations for video game play in the context of normal development. Review of General Psychology, 14(2), 180-187. https://doi.org/10.1037/ a0018984

Pearson, W. J. (1976). Tycoon: The international shipping game [Board game]. Game Cards International.

Podolefsky, N. (2012). Learning science through computer games and simulations. Studies in Science Education, 48(2), 237240. https://doi.org/10.1080/03057267.2012.720770

Prensky, M. (2001). The Digital Game-Based Learning Revolution. Learning, 1(1), 1-19. https://doi.org/10.1016/j. iheduc.2004.12.001

Programme Structure (L\&T) - UUM. (2016). Retrieved from http:// stmlportal.net/index.php/programmes/undergraduate/menutypes/programme-structure-bom 
Radzi, S. H. M., Abidin, M. Z. Z., Zainol, A. Z., \& Ahmad, P. A. (2015a). Board game pengurusan pelabuhan: Satu pendekatan pembelajaran inovatif.

Radzi, S. H. M., Abidin, M. Z. Z., Zainol, A. Z., \& Ahmad, P. A. (2015b). Sanglang: Get hooked! [Board game].

Radzi, S. H. M., Abidin, M. Z. Z., Zainol, A. Z., \& Ahmad, P. A. (2017). Penang Port: A port management game [Board game]. Rastegarpour, H., \& Marashi, P. (2012). The effect of card games and computer games on learning of chemistry concepts. Procedia - Social and Behavioral Sciences, 31(2012), 597601. https://doi.org/10.1016/j.sbspro.2011.12.111

Salen, K., \& Zimmerman, E. (2004). Rules of Play - Game Design Fundamentals. The MIT Press.

Saunders, D. (2004). Shipping Empires [Board game]. DS Games.

Schneider, B., Blikstein, P., \& Mackay, W. (2012). Combinatorix : A tangible user interface that supports collaborative learning of probabilities. In ITS ' 12 Proceedings of the 2012 ACM international conference on Interactive tabletops and surfaces, 129-132.

Spring, D. (2015). Gaming history: Computer and video games as historical scholarship. Rethinking History, 19(2), 207-221. https://doi.org/10.1080/13642529.2014.973714

Tan, W. H. (2015). Gamifikasi dalam pendidikan: Pembelajaran berasaskan permainan. Tanjong Malim, Perak: Universiti Pendidikan Sultan Idris. p.1-10.

Tan, W. H., Johnston-Wilder, S., \& Neill, S. (2011). Game-Based Learning with a Dialogic Teaching Approach. In Handbook of Research on Improving Learning and Motivation through Educational Games (pp. 860-875). IGI Global. https://doi. org/10.4018/978-1-60960-495-0.ch039

The north atlantic shipping game [Board game]. (1980). Trans Freight Lines.

UNCTAD. (2015). Review of maritime transport 2015. United Nations.

Veloo, A., Md-Ali, R., \& Chairany, S. (2016). Using cooperative teams-game-tournament in 11 religious school to improve mathematics understanding and communication. Malaysian Journal of Learning and Instruction, 13(2), 97-123.

Wait, M., \& Frazer, M. (2018). Investigating retention and workplace implementation of board game learning in employee development. Acta Commercii - Independent Research Journal in the Management Science, 18(1), 1-7. 
Yusof, S. A. M., Radzi, S. H. M., Khalid, S. N. S., \& Din, N. (2016). A study on the effectiveness of Task Manager board game as a training tool in managing project. In International Soft Science Conference. Institute for Research \& Innovation Management Centre (RIMC), Universiti Utara Malaysia.

Zin, N. A. M., Jaafar, A., \& Yue, W. S. (2009). Digital game-based learning (DGBL) model and development methodology for teaching history. WSEAS Transactions on Computers, 8(2), 322-333. 